\title{
Selection for Increased Budbreak in Apple
}

\author{
Iwan F. Labuschagné, ${ }^{1}$ J.H. Louw, ${ }^{2}$ Karin Schmidt, and Annalene Sadie ${ }^{3}$ \\ ARC Infruitec-Nietvoorbij (The Fruit, Vine and Wine Research Institute of the Agricultural Research \\ Council), Private Bag X5013, Stellenbosch, 7599, Western Cape, South Africa
}

\begin{abstract}
ADDiTIONAL INDEX wORDS. Malus sylvestris, prolonged dormancy symptoms, chilling requirement, climatic adaptability, fruit tree breeding, two-way selection, selection response, realized heritability, combined selection

AbSTRact. Significant response to selection for budbreak number (NB) based on data recorded on 1-year-old shoots of young apple (Malus sylvestris (L.) Mill var. domestica (Borkh.) Mansf.) seedlings (Expt. I) and branches from adult seedling trees (Expt. II) has been demonstrated in clonally propagated seedling trees. Between family variation for NB was low and masked by year $\times$ family interaction effects. Realized heritability for NB was estimated as $40 \%$ to $60 \%$. Correlated response in uniformity and position of budbreak, and in the number and length of side shoots, was found. Association between the time of budbreak (TB) and NB, according to midparent and cross groupings, and according to the parental means, indicate a positive genetic correlation between these traits. Where data on adult trees were used as a measure of selection response and tested on young clonal trees, significant response and genetic variation was shown, confirming the presence of utilizable genetic variance and that this procedure may be successfully applied as an early screening method for increased budbreak in adult trees. Combined selection utilizing genetic variance between crosses as well as within crosses is proposed as the best procedure to increase the frequency of seedlings with increased budbreak and to improve adaptation to low winter chilling conditions.
\end{abstract}

Apple (Malus sylvestris (L.) Mill var. domestica(Borkh.) Mansf.) is the most economically important deciduous fruit crop in the Western Cape Province of South Africa. There are four major production areas, viz, Elgin $\left(34^{\circ} \mathrm{S}, 305 \mathrm{~m}\right.$, ca. 850 Utah Chill Units (CU)), Koue Bokkeveld $\left(33^{\circ} \mathrm{S}, 945 \mathrm{~m}, \mathrm{ca} .1300 \mathrm{CU}\right)$, Langkloof $\left(33^{\circ} \mathrm{S}, 722 \mathrm{~m}\right.$, ca. $700 \mathrm{CU})$ and Vyeboom $\left(34^{\circ} \mathrm{S}, 309 \mathrm{~m}\right.$, ca. $\left.700 \mathrm{CU}\right)$, which contribute respectively, $28 \%, 21 \%, 21 \%$ and $13 \%$ to the total orchard area. Commercial cultivars develop abnormalities in growth behavior referred to as prolonged dormancy symptoms (PDS) (Jacobs, et al., 1981; Janick et al., 1996), because winters are not cold enough to satisfy winter chilling requirement (CR). Low winter chilling, fluctuations in temperature with exceptionally hot days and extended cold accumulation towards the end of winter and spring commonly occur. While temperatures in the Koue Bokkeveld are sufficiently cold for normal initial development of bud dormancy, the winters are normally too short for normal dormancy release. Producers in areas with low chilling conditions apply chemical agents in an attempt to induce more uniform budbreak and in order to achieve better fruit set and fruit quality. Dinitro-ortho-cresol mineral oil (DNOC) has been used but due to environmental and health concerns the product is to be phased out by 2005 .

Dormancy is generally defined as the temporary suspension of visible growth of any plant structure containing a meristem, e.g., vegetative and reproductive buds (Lang et al., 1987) and may represent a continuous gradient of regulatory events or phases (Lang et al., 1985). Chilling requirement relates to the need for exposure to low temperatures for temperate fruit trees to be released from dormancy and to commence proper growth (Howe et.al., 1999). If CR temperatures do not occur during the rest period or when dormancy release is not successful, an absence or long delay of lateral vegetative and reproductive budbreak occurs (Cook, et al.,

Received for publication 8 May 2002 Accepted for publication 23 Dec. 2002. This study was funded by the South African Fruit Producers Trust. The paper was submitted by the senior author in partial fulfillment of the requirements for a PhD degree in genetics.

${ }^{1}$ Corresponding author; e-mail iwan@infruit.agric.za.

${ }^{2}$ Senior lecturer in genetics, Faculty of Agriculture and Forestry Sciences, Department of Genetics, Stellenbosch University, Matieland, 7602, Western Cape, South Africa.

${ }^{3}$ Lecturer in biometry, Faculty of Agriculture and Forestry Sciences, Department of Genetics, Stellenbosch University, Matieland, 7602, Western Cape, South Africa.
1998; Hauagge and Cummins, 1991a; Mauget and Rageau, 1988). The length of the delay is directly related to the lack of chilling and the less the chilling received the more uneven the pattern of budbreak (Mauget and Rageau, 1988).

For important horticultural traits, such as yield and fruit quality, it is unrealistic to expect levels of performance of cultivars to be the same in all environments. This is the main reason why some cultivars developed in other countries are not suitable for local production. Hence, there is an urgent need to develop cultivars better adapted to local low chilling conditions. Knowledge about the genetic variance and inheritance of traits associated with CR is a prerequisite for the development of adapted cultivars by breeding and selection. Generally, CR is seen as a complex genetically determined trait, probably multigenic or partly controlled by multiple genes (Dennis, 1987; Howe et al., 1999). The genetics of CR measured in terms of prolonged dormancy symptoms has not been adequately investigated and the genetic variability of budbreak number as selection criterion in planned breeding programs in fruit trees has not been assessed. Therefore, the aim of our study was to assess the potential of genetic manipulation and utilization of genetic variation in CR to provide guidelines for the design of such programs. Other breeding aims in the program include fruit quality traits and disease resistance.

Since vegetative budbreak under normal chilling is prolific and occurs uniformly in a relatively short period of time we have examined response to selection based on the number of buds breaking as a criterion of selection against PDS. Specifically, the aims of our study were to evaluate 1) direct response to selection for high and low budbreak within families, 2) possible correlated responses in other related traits, and 3) residual genetic variance for budbreak in young seedlings. The experimental procedure of two-way truncation selection, high and low, was adopted since this provides the best possible experimental control for the measurement of response under conditions of limited available resources, i.e., in this case better than maintaining control populations of equal size in which no selection is applied (Falconer and MacKay, 1996).

\section{Materials and Methods}

Plant material and selection procedures

EXPERIMENT I. FAMILIES DERIVED From 'ANNA' AND 'Royal 
GALA'. In this experiment data from young seedlings were used to select seedlings with high and low number of budbreak and the selection response was verified on young clonal trees propagated from these original seedlings. The initial material consisted of a very large population of 2 -year-old seedlings, $\approx 3400$, planted in 1-L plastic planting bags during 1994, comprising 11 families and average family size of 280 seedlings. 'Anna' (An) was the common parent in two families with 'Braeburn' $(\mathrm{Br})$ and 'Royal Gala' (RG). 'Royal Gala' was the common parent in nine families with Br, 'Priscilla' (Ps), 'Full Red' (FR), 'Red Chief' (RC), 'Fuji' $(\mathrm{Fu})$, 'Fiesta' (Fi), 'Lady Williams' (LW) and 'Jona Red' (JR). A preselection based on visual evaluation of NB was applied in 1-year-old shoots towards the middle of the growing season in December 1995. Two groups were selected, one for high NB $(\mathrm{H}$ selection) and one for low NB (L selection). About $45 \mathrm{H}$ and 45 L seedlings were visually selected within each family. By visual evaluation we could screen the entire population relatively quickly and obtain the highest possible selection intensity for the limited facilities available for the program later.

After the visual preselection, the actual number of buds breaking was counted and expressed as the NB per $100 \mathrm{~cm}$ length of shoot. During the following 3 years $(1996,1997,1998)$ both TB and NB were recorded on each individual seedling. NB was scored $21 \mathrm{~d}$ after initial budbreak at the time when leaves started to emerge from a vegetative bud. Seedlings were cut back and regrown each year to establish strong growing 1-year-old shoots.

Further selections within the $\mathrm{H}$ and $\mathrm{L}$ groups were performed based on NB scores averaged over the period of three consecutive years after the initial visual preselection. Twenty seedlings across families of each of the $\mathrm{H}$ and $\mathrm{L}$ groups were selected according to the NB scores and cloned by budding on M793 rootstock in a nursery. The clones of selected seedlings were transplanted to plastic bags during the following season and grouped in a randomized blocks experiment to evaluate selection response as the difference between the $\mathrm{H}$ and $\mathrm{L}$ group means. Trees were allowed to develop without pruning or any other growth manipulation.

Experiment II. Selections from 'Anna' and 'Golden DeLICIOUS' FAMILIES. In this experiment, data from adult seedling trees were used to select seedlings with high and low number of budbreak and the selection response was verified on young clonal trees propagated from these original adult trees. Seedlings were selected for high and low NB based on the numbers of vegetative and reproductive buds breaking on adult trees collected over the period of three years (1996, 1997, and 1998) (Labuschagné et al., 2002a). These trees originated from families of two different sets of crosses, viz, four families with the high chill 'Golden Delicious' as parent and four families with the low chill 'Anna' as parent. Trees from 'Golden Delicious' and 'Anna' planted in orchards for fruit evaluation purposes were, respectively, 7 and 5 years old. 'Golden Delicious' was used as a common parent in crosses with 'Prima' (Pr), 'Summerking'(Su), 'Starking Delicious' (St) and 'Braeburn' (Br). 'Anna' was used as a common parent in crosses with 'Austin' (Au), 'Sharpe's Early'(SE), 'Kirks'(Ki) and 'Summerred' (Sr). 'Anna' has one of the lowest chilling requirements found in Malus $\times$ sylvestris (Brooks and Olmo, 1972), \pm 300 CU, compared to $\pm 1500 \mathrm{CU}$ for 'Golden Delicious' (Hauagge and Cummins, 1991a). Of the other parents CR records were available only for 'Braeburn' ( $\pm 1100 \mathrm{CU})$, 'Prima' ( $\pm 1100 \mathrm{CU})$ and 'Summerred' ( \pm 999 CU) (Hauagge and Cummins, 1991a; Hauagge, personal communication).

Based on the data, 13 to 15 seedlings were selected for each of the $\mathrm{H}$ and $\mathrm{L}$ groups out of a total of 60 seedlings scored per family. Selected seedlings were clonally propagated by budding on M793 rootstock in a nursery. The clonal trees were transplanted to plastic bags during the following season and arranged in a randomized block experiment to evaluate selection response, again as the difference between $\mathrm{H}$ and $\mathrm{L}$ groups and to evaluate residual variation within $\mathrm{H}$ and $\mathrm{L}$ groups. The trial consisted of five blocks with single trees from the two selection groups within each block. Parental cultivars of the same age of the seedling clones used in the crosses were included in the trial as well for the purpose of comparison of midparent values with $\mathrm{H}$ and $\mathrm{L}$ groups for the various crosses. Trees were allowed to develop without pruning or any other tree growth manipulation. The first data were collected during the 2000 growing season.

MEASUREMENTS RECORDED IN CLONAL TRIALS. The following measurements were recorded on young trees after clonal propagation: NB, $21 \mathrm{~d}$ after initial vegetative budbreak, TB, the number and length of side shoots, the total number of nonsprouted buds (Expt. I), shoot circumference (Expt. I) and the total shoot lengths on each seedling (I and II). The number of shoots was recorded in the following classes: $(5 \mathrm{~cm}, 6$ to $15 \mathrm{~cm}, 16$ to $30 \mathrm{~cm}$ and $>30$ $\mathrm{cm}$. NB was again expressed as the number of budbreak per 100 $\mathrm{cm}$ length of shoot. Data were recorded on four equal sections (section 1 lower to section 4 upper) over the length of the tree. The number of side shoots during the first season was recorded. These shoots are also known as sylleptic shoots that develop on vigorously growing shoots concurrent with development of the main shoot, without a resting phase (Champagnat, 1978; Cook, et al., 1998). Cold units (CU) were calculated according a modified Utah-model (Linsley-Noakes et al., 1994).

ANALYSIS OF SELECTION DATA. The characteristics (traits) we are dealing with are quantitative measurements in pedigreed family groups. Hence, results can be analyzed and presented in terms of the methods and concepts of quantitative genetics (Falconer and Mackay, 1996). The approach fully acknowledges the fact that what one ultimately measures at the phenotypic level is the outcome of more or less complex underlying physiological and developmental processes which are not always directly indentifiable and measurable but under genetic control and sensitive to environment. The major thrust is then to estimate the genetic and environmental components of variance in order to formulate selection strategies. The analysis uses the standard prediction formula for response to truncation selection, viz, $R=H S$ where $S$ is the selection differential, i.e., the difference between means of high and low selection groups in the case of two-way selection, and $H$ is the ratio of genetic variance $\left(V_{G}\right)$ to phenotypic variance $\left(V_{P}\right)$ for the trait in the population under selection. When $R$ and $S$ are calculated from actual data as in the present experiments the estimate of $H$ is $R / S$, known as the realized heritability and strictly applies to the particular population (Falconer and Mackay, 1996). The usage requires some qualification as follows.

1) The population under selection is the family of a cross between cultivars of which the genomes are likely to be highly heterozygous, including loci for the trait of interest. Genetic variance of the trait therefore refers to total genetic variance including additive, dominance and epistatic components. $H$ is then referred to as broad sense heritability (Falconer and Mackay, 1996).

2) Selection response, $R$, refers to follow-up measurements repeated on selected individuals (seedlings), and not to progenies of selected individuals as is the usual usage. Follow-up measurements in these experiments were made on the same seedlings in seasons subsequent to selection, or on vegetative clones of selected seedlings. 
3) The usage is in keeping with the prediction of response in so-called one-step selection in plant breeding, i.e., selection in populations consisting of fixed (and reproducible) genotypes such as inbred lines and line crosses (Wricke and Weber, 1986). In apples and other tree crops, reproduction of genotypes is accomplished by vegetative cloning.

4) Since estimation relies on observed selection differential and response, no assumption of normality in the distribution of the trait is required, i.e., $R / S=V_{G} / V_{P}$ is the regression of genotype on phenotype in the conventional sense regardless of the underlying distribution.

5) Families of seedlings such as those for common parents 'Royal Gala', 'Anna' and 'Golden Delicious' in crosses with other cultivars are sets of full-sib families and the two-way selection was within families. Any ongoing program of crossing and selection would presumably aim to use genetic variance between families as well, by selection based on individual seedling performance (or the mean seedling clone performance) $P_{w}$, combined with the family mean, $P_{f}$. If $P_{w}$ is expressed as a deviation from the family mean and $P_{f}$ as a deviation from the population mean, the standard index for combined selection is applicable, viz,

$I=k_{w} P_{w}+k_{f} P_{f}$, where $k_{w}=(1-\mathrm{r}) /(1-\mathrm{t})$ and $k_{f}=[1+(n-1) r] /[1$ $+(n-1) t]$, where $n$ is the family size, $r$ the family relationship $(=$ $1 / 2$ for full-sibs) and $t$ the intraclass correlation for the trait within families (Falconer and Mackay, 1996). The residual variance of NB in the three sets of crosses may then be analyzed in these terms with the aim of formulating the next step of a program of selection for this material and a future program of crossing involving other genetic resources.

GeNERAL DATA ANALYSIS. Analysis of variance (ANOVA) was carried out for all measurements for each year and for all years to test for year $\times$ family interaction effects where applicable. The year $\times$ family interaction mean square was used as error term in the ANOVA to test significant differences between families in Expt. I. ANOVA to investigate differences between selection groups for individual years was also based on selection $\times$ family interaction terms. The analyses were performed using SAS General Linear Model procedures (SAS Institute, Inc., 1996) after testing for heterogeneity of variance by means of the Levene test (Snedecor and Cochran, 1991) and the Shapiro-Wilk test for normality (Shapiro and Wilk, 1965). Data sets were weighted for homogeneity of variance and transformed to obtain closer approximations to the normal distribution where necessary. Multiple comparisons were performed using Student's $t$ LSD test. Correlation analyses were performed using the SAS Correlation procedure.

\section{Results}

Response to selection for budbreak number within families

EXPERIMENT I. Significant differences were detected between the $\mathrm{H}$ and $\mathrm{L}$ selection groups for $\mathrm{NB}$, indicating significant selection response over the set of 11 crosses (Fig. 1). Some families showed greater response, e.g., 'Anna X 'Braeburn', and in others a lower response to selection was found, e.g., 'Royal Gala' $x$ 'Fiesta'. The response was positive and significant over the full period of three years after the initial visual selection (Table 1). The response $(R)$ calculated as the difference between $\mathrm{H}$ and $\mathrm{L}$ overall means translates to a realized heritability of $\approx 44 \%$, where the selection differential $(S)$ was calculated from mean NB counts after the initial visual selection.

Response to the second phase of selection was verified in the clonal trial over the 2 following years containing 20 selections in each group. Significant differences between the selection groups were again clearly evident (Fig. 2, Table 2). A distinct difference in growth habit between the selection groups during the first year was also evident as illustrated in Fig. 3. NB on the main shoots of the $\mathrm{H}$ group (sections 1 to 4 ) was more uniform compared to the L group and the L group showed higher NB in the upper parts (sections 3 and 4 ) of the main shoots (Table 3). Allthough the $\mathrm{H}$ values were higher than the $\mathrm{L}$ values for all sections during the second year of this trial, higher NB was evident in the lower parts of trees in the $\mathrm{H}$ group compared to the $\mathrm{L}$ group. This may be explained by the greater extent of side shoot development in the $\mathrm{H}$ group. $\mathrm{NB}$ in the $\mathrm{L}$ group remained higher in sections 3 and 4 (Table 3). The observed selection differentials and responses in this phase of selection translates to a realized heritability of $\approx 53 \%$.

EXPERIMENT II. Significant differences for NB between the $\mathrm{H}$ and L groups were evident in 'Anna' $(P \leq 0.01)$ and 'Golden Delicious' selections ( $P \leq 0.01)$ (Fig. 4A and B, respectively). On average, 'Anna' selections had a lower mean (12.94) than 'Golden Delicious' (15.21) $(P \leq 0.01)$, in agreement with the observed difference between these two common parental cultivars grown in the same trial. Realized heritability calculated from the selection differential and response to selection was $\approx 63 \%$ in 'Anna' families and $40 \%$ in 'Golden Delicious' families (Table 4). Both $\mathrm{H}$ and $\mathrm{L}$ groups were consistently lower than the midparent value in all 'Golden Delicious' crosses and in one 'Anna' cross (with 'Summerred'). These are unexpected results in terms of quantitative genetics unless heterosis (in these cases negative) is associated with these crosses and will have to be explored further.

\section{Correlated response in budbreak time}

EXPERIMENT I. Significant differences between 'Anna' and 'Royal Gala' families were evident for TB. 'Anna' selections were recorded as $28 \mathrm{~d}$ earlier in the $\mathrm{H}$ group and $46 \mathrm{~d}$ earlier in the L group. Within 'Anna' families, the $\mathrm{H}$ group was $14 \mathrm{~d}$ later than the L group, and in 'Royal Gala' families the $\mathrm{H}$ group was

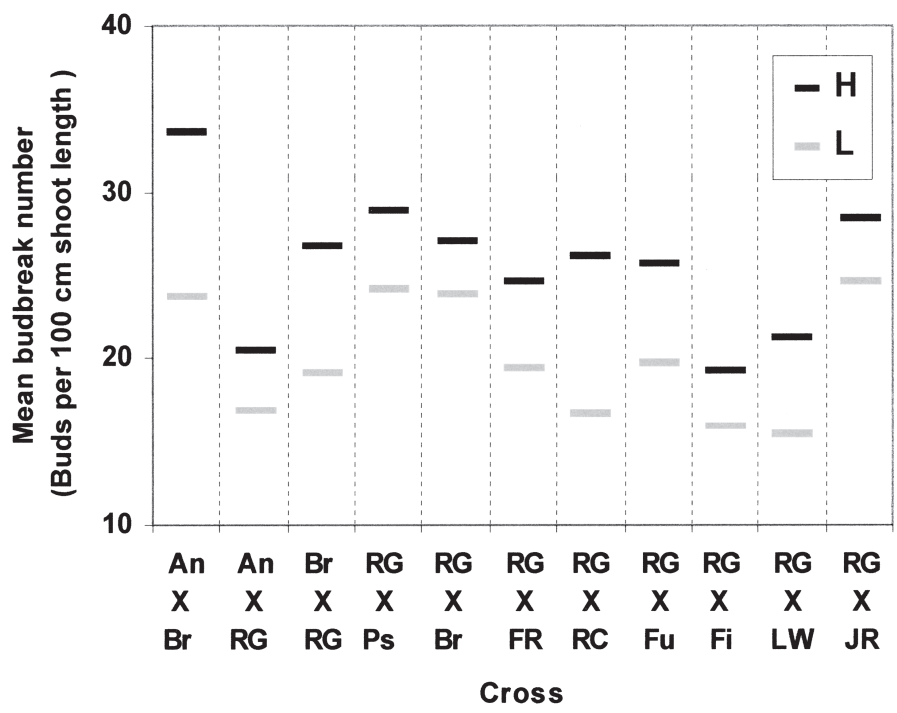

Fig. 1. Response to initial selection for high $(\mathrm{H})$ and low $(\mathrm{L})$ budbreak number within individual families (crosses) averaged over three trial seasons (1996-98). Selection was based on visual evaluation in 1995. 'Anna' (An) was the common parent in two families with 'Braeburn' (Br) and 'Royal Gala' (RG). 'Royal Gala' was the common parent in families with Br, 'Priscilla' (Ps), 'Full Red' (FR), 'Red Chief' (RC), 'Fuji' (Fu), 'Fiesta' (Fi), 'Lady Williams' (LW) and 'Jona Red' (JR). 
Table 1. Mean response to selection for high $(\mathrm{H})$ and low $(\mathrm{L})$ budbreak number averaged over all families (crosses) for initial visual selection within families.

\begin{tabular}{|c|c|c|c|c|c|c|}
\hline \multirow[b]{3}{*}{ Parameter } & \multicolumn{5}{|c|}{ Mean budbreak no. } & \\
\hline & Selection & & & Response & & \\
\hline & 1995 & 1996 & 1997 & 1998 & Mean (1996-98) & Realized heritability \\
\hline$\overline{\mathrm{H}}$ & $16.52^{\mathrm{z}}$ & $38.28 \pm 1.90$ & $21.84 \pm 1.11$ & $16.88 \pm 1.43$ & $25.67 \pm 1.87$ & \\
\hline $\mathrm{L}$ & $3.86^{\mathrm{z}}$ & $31.14 \pm 1.90$ & $15.52 \pm 1.11$ & $13.32 \pm 1.43$ & $19.99 \pm 0.87$ & \\
\hline Mean & & 34.71 & 18.68 & 15.10 & & 0.44 \\
\hline
\end{tabular}

${ }^{\mathrm{z}}$ Scored after initial visual selection.

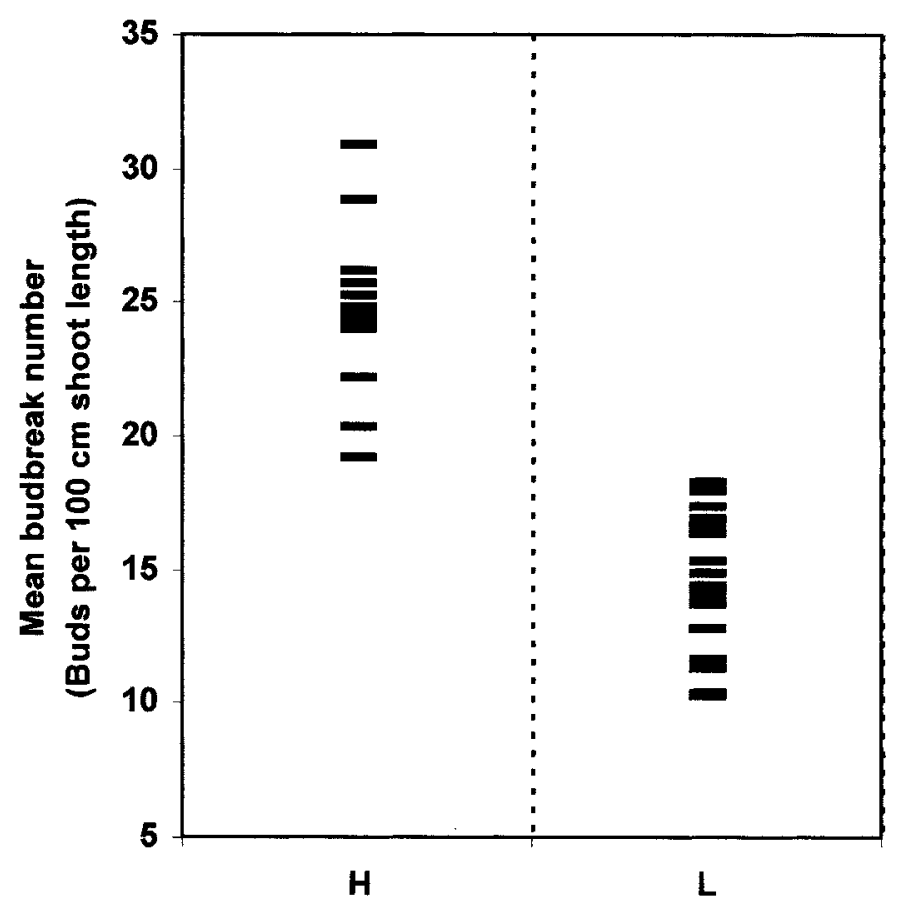

Selection

Fig. 2. Response to second phase selection for high $(\mathrm{H})$ and low $(\mathrm{L})$ budbreak number averaged over two trial seasons (1999-2000). Selection of the 20 families (crosses).

$4 \mathrm{~d}$ earlier than the L group.

EXPERIMENT II. In the correlated response of TB, large differences between 'Anna' and 'Golden Delicious' selections were found. On average TB of 'Anna' selections were 42 days earlier than 'Golden Delicious' $(P \leq 0.01)$ (Fig. 4C and D), and budbreak occurred over a more prolonged period in 'Anna' selections. Budbreak in $\mathrm{H}$ groups occurred significantly later than in L groups of 'Anna' selections, and earlier in the $\mathrm{H}$ groups of 'Golden Delicious' selections. Midparent values for TB in highest and 20 lowest was based on 3-year means (1996-98) after pooling all

'Golden Delicious' selections were generally higher than $\mathrm{H}$ and L group means and lower than the H groups in 'Anna', except for 'Austin' and 'Sharpe's Early' in the L groups.

The genetic association between TB and NB may be analyzed in various ways in this material, in terms of means of midparent and cross groupings (Fig. 5A), where cross performance is estimated using the overall means of $\mathrm{H}$ and $\mathrm{L}$ groups, and in terms of parental means taken on their own (Fig. 5B). Taking parents alone (Fig. 5B), a positive genetic association $(r=0.679)$ is evident. Another approach is the regression of cross means for one trait (TB) on midparent values for the second trait (NB) and vice versa, as is done in parent-offspring investigations of genetic correlation between traits (Falconer and Mackay, 1996). This is illustrated in Fig. 6 and again confirms a positive genetic association between TB and NB at this level, i.e., 'Anna' and 'Golden Delicious' parental and cross groups.

\section{Correlated response in other traits}

EXPERIMENT I. Following the second selection cycle, budbreak expressed as percentage of total buds was higher in the $\mathrm{H}$ group than in the L group. Significant differences between $\mathrm{H}$ and L groups for uniformity and position of budbreak, and the number and lengths of side shoots in the cloned seedlings were evident (Table 3). Side shoots were longer in the $\mathrm{H}$ group compared to $\mathrm{L}$ in both years. Strong growing shoots (shoots exceeding the mean length of all long shoots) in the lower part of trees were 57\% in the $\mathrm{H}$ group and 50\% in L. Means for main shoot length, shoot circumference and internode length did not differ significantly between the selection groups. The $\mathrm{L}$ group showed slightly more total buds on main shoots compared to $\mathrm{H}$. More seedlings in the L group had no shoots forming and no buds breaking during both years (data not shown).

EXPERIMENT II. 'Anna' had significantly higher reproductive budbreak than 'Golden Delicious' $(P \leq 0.01)$. More reproductive buds occurred on trees in the $\mathrm{L}$ group than in the $\mathrm{H}$ group. This was also observed for the number of side shoots where the $\mathrm{H}$ group produced more shoots. 'Austin' and 'Summerred' had the highest number of reproductive budbreak and 'Kirks' and 'Anna' produced the highest numbers of side shoots.

\section{Between family variance}

Table 2. Mean response to selection for high (H) and low (L) budbreak number averaged over all families (crosses). Selection on three-year means (1996-98), all families pooled.

\begin{tabular}{|c|c|c|c|c|c|}
\hline \multirow[b]{3}{*}{ Parameter } & \multicolumn{5}{|c|}{ Mean budbreak no. } \\
\hline & \multirow{2}{*}{$\begin{array}{c}\text { Selection } \\
1996-98\end{array}$} & \multicolumn{4}{|c|}{ Response } \\
\hline & & 1999 & 2000 & Mean (1999-2000) & Realized heritability \\
\hline$\overline{\mathrm{H}}$ & 37.98 & $34.27 \pm 1.11$ & $15.49 \pm 0.53$ & $24.88 \pm 0.62$ & \\
\hline Mean & & 27.39 & 12.37 & 19.87 & 0.53 \\
\hline
\end{tabular}


EXPERIMENT I. After the initial visual two-way mass selection, significant differences between families were found in both the $\mathrm{H}$ and $\mathrm{L}$ groups $(P \leq 0.01)$. During the 3 years following the initial selection, yearly variation masked family differences. Multiple comparisons suggest low genetic variation for NB between families when year $\times$ family interaction was applied as error term during this period.

EXPERIMENT II. Means for NB suggest that 'Austin' and 'Summerred' selections have low NB, whereas 'Prima', 'Kirks' and 'Summerking' have intermediate NB, and 'Starking Delicious', 'Braeburn' and 'Sharpe's Early' high NB (Table 5). Parental means for 'Kirks', 'Prima' and 'Anna', are low (Table 6), 'Sharpe's Early', 'Austin' and 'Summerred' intermediate and 'Summerking', 'Golden Delicious' and 'Braeburn'high. 'Starking Delicious' was consistently superior in NB. Within the 'Anna' crosses, 'Anna' $x$ 'Austin' was early in budbreak and 'Anna' $x$ 'Summerred' late.
Differences between 'Golden Delicious' crosses for TB were not statistically significant. Parental means differed significantly for TB (Table 6), with 'Anna' the earliest and 'Golden Delicious' and 'Summerking' the latest. 'Austin' and 'Kirks' can be regarded as early cultivars and 'Summerking', 'Starking Delicious', and 'Prima', as late cultivars according to these results.

AnALYSIS OF SELECTION RESPONSE. Results of the analysis of residual variance in the three sets of crosses having one parent in common in the two experiments are further summarized in Table 7, giving the intraclass correlation coefficients, $t$, and the derived weights $k_{w}$ for $P_{w}$ and $k_{f}$ for $P_{f}$ the latter calculated for family sizes of 5,10 , and 20 which should more or less cover the range of family sizes possible in follow-up testing and selection in this material.

AGE-AGE CORrelations. Correlation analyses were performed to test the association between measurements on 2-year-old seed-
A
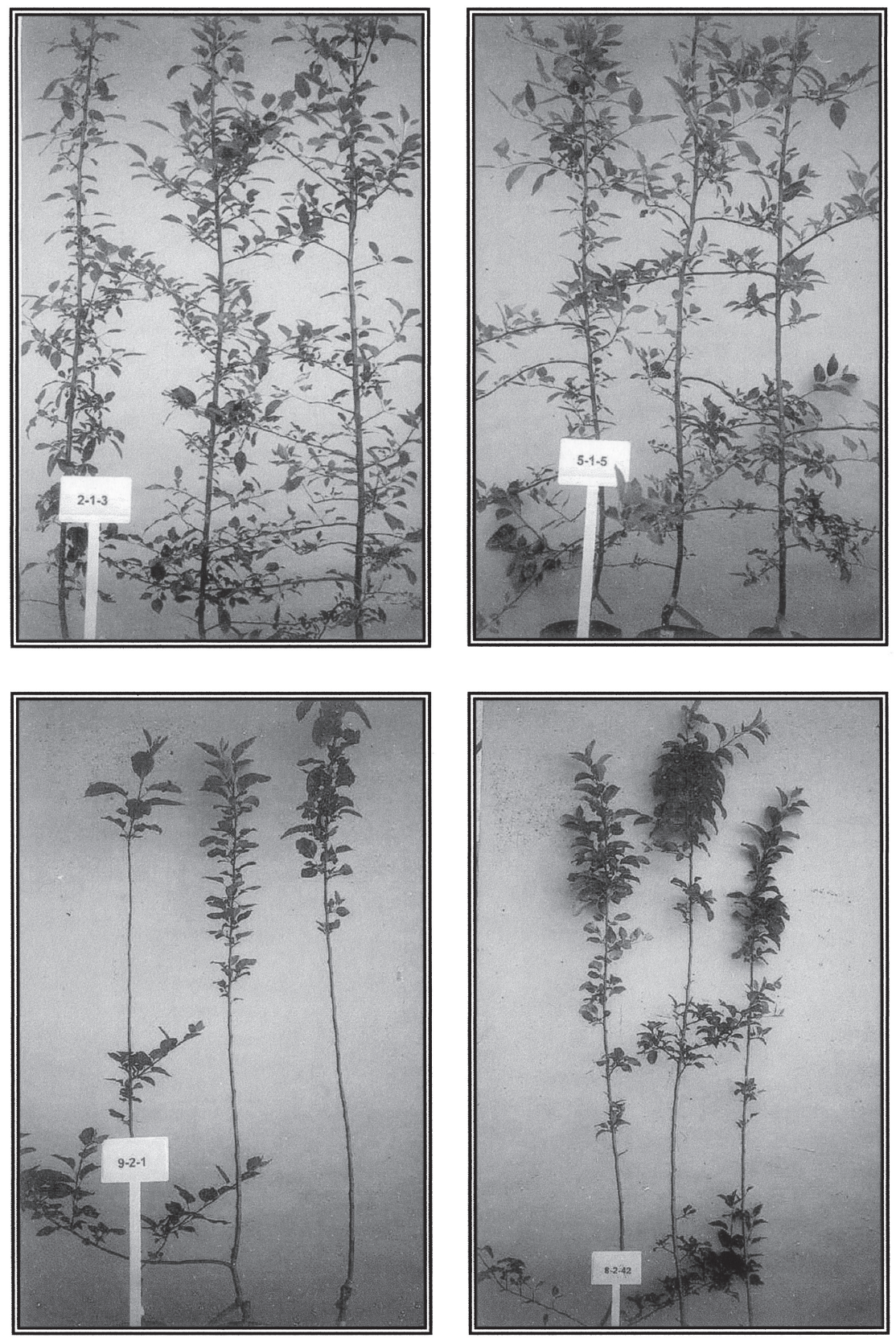

Fig. 3. Clones of cross seedlings selected for (A) high and (B) low budbreak number, one year after budding on M793 rootstocks (second growing season). One photo represents three clones of one seedling selection.
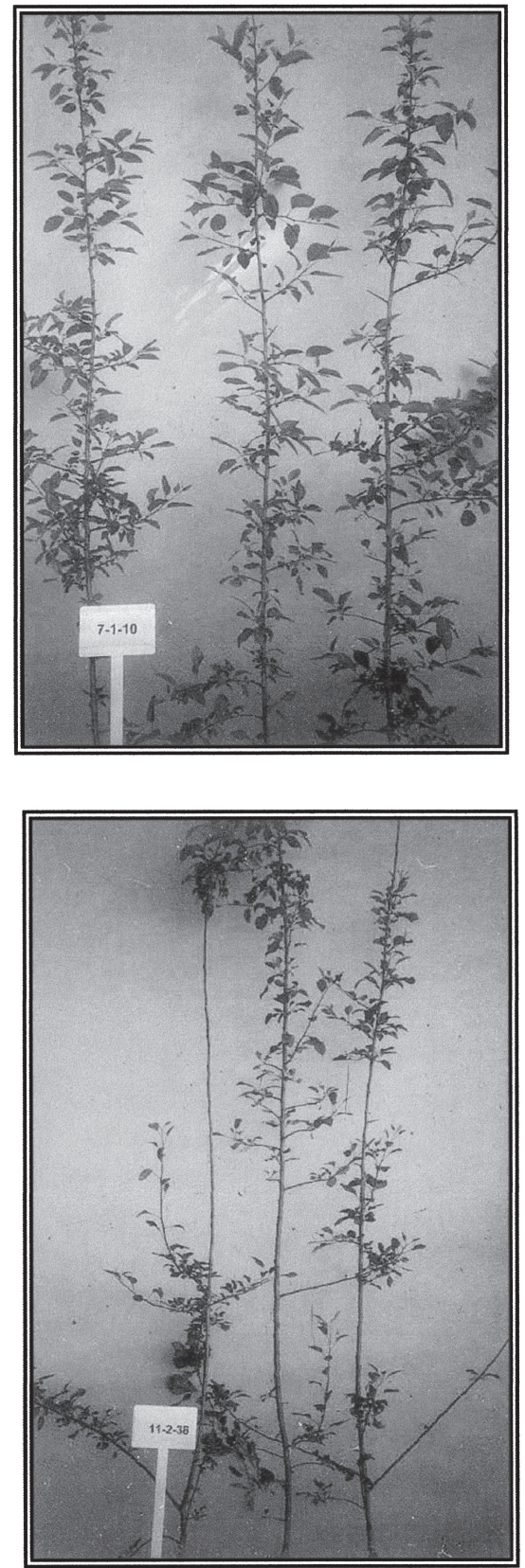
ling clones and measurements on the original adult parental trees on which the selection in Expt. II was based (Table 8). The first year's set of data on adult trees was recorded during 1996 in the seventh growing year of the 'Golden Delicious' families and the fifth growing year of the 'Anna' families. Correlation analysis based on covariance indicates a positive association between adult and 2-year-old seedlings for TB in the L group $(r=0.363)$ and in the $\mathrm{H}$ group $(r=0.493)$, and for NB in the $\mathrm{L}$ group $(r=0.313)$ and for the $\mathrm{H}$ group $(r=0.127)$.

\section{Discussion}

A significant response to selection in opposite directions for high and low NB was obtained in clonally propagated trees based on records of 1-year-old shoots of young seedlings and branches from adult trees. In Expt. I, NB counts during three seasons following preselection clearly confirm a genetic basis for the observed variation. In Expt. II, where data on adult trees were used as a measure of selection response and tested on young clonal trees, significant response and genetic variation was also found. The highest realized response for NB occurred in 'Austin', 'Sharpe's Early' and 'Summerred' selections derived from 'Anna' crosses. Correlated selection response for TB was generally higher in 'Anna' crosses than in 'Golden Delicious' crosses.

Correlated responses between families for NB and TB showed some similarities within the 'Golden Delicious' and 'Anna' groups, but differences between the two groups were clearly evident with regard to family means and midparent values. Midparent values for NB and TB in 'Golden Delicious' were generally higher than for $\mathrm{H}$ and $\mathrm{L}$ selection means. Discrepancies in midparent values between 'Golden Delicious' and 'Anna' can perhaps only be explained by the relationships between parents that were used in crosses, i.e., 'Anna' was selected from a backcross population which had one, low chill requiring Israeli seedling as the main gene source (Stushnoff and Quamme, 1983).

Realized heritabilities for NB were estimated between $40 \%$ and $60 \%$. In Expt. II the realized heritability was $\approx 65 \%$ for 'Anna' families and $40 \%$ for 'Golden Delicious' families. In previous experiments performed locally, estimates of genetic components of variance between and within families in the absence of selection gave estimates of broad sense heritability for NB at $\approx 30 \%$ (Labushagné et al., 2002a). Broad sense heritability estimates from studies performed on dormancy and related traits in trees include reproductive budbreak time in almond (Prunus amygdalus Batsch): 80\% (Kester et al., 1977), in apricot (Prunus armeniaca L.): 94\% (Couraujou et al., 1995), in cherry (Prunus avium L): 65\% (Hansche et al., 1966), in peach [Prunus persica (L.) Batsch]: 39\% (Hansche et al., 1972), and in apple: 67\% (Hauagge and Cummins, 1991b). For degree of adaptability based on budbreak number in apple a heritability estimate of $36 \%$ (Hauagge and Cummins, 1991b) and for blind node propensity in peach, $23 \%$ (De Souza and Byrne, 1998). In general, it appears that the heritability of dormancy traits related to budbreak time can be regarded as intermediate to high and these traits should respond positively to selection.

Correlated responses to selection for NB were found in the uniformity and position of budbreak, and in the number and lengths of side shoots. After the second selection cycle in Expt. I, differences between selection groups $\mathrm{H}$ and $\mathrm{L}$ were clearly evident and characterized by a more active growth pattern in the $\mathrm{H}$ group

Table 3. Variation in tree characteristics of seedling clones selected for high and low NB. $P$ values indicate differences between the H and L selection groups.

\begin{tabular}{|c|c|c|c|c|c|c|c|}
\hline \multirow{2}{*}{\multicolumn{2}{|c|}{ Trait }} & \multicolumn{3}{|c|}{ Year 1 (1999) } & \multicolumn{3}{|c|}{ Year $2(2000)$} \\
\hline & & $\mathrm{H}$ & $\mathrm{L}$ & $P$ & $\mathrm{H}$ & $\mathrm{L}$ & $P$ \\
\hline \multicolumn{8}{|c|}{ Number of budbreak (NB)y } \\
\hline \multicolumn{2}{|c|}{ Total tree length } & 34.27 & 20.50 & 0.0001 & 15.49 & 9.25 & 0.0001 \\
\hline \multirow{3}{*}{ Section } & 2 & 8.53 & 5.16 & 0.0001 & 4.28 & 2.30 & 0.0001 \\
\hline & 3 & 8.24 & 6.30 & 0.0001 & 3.87 & 2.63 & 0.0001 \\
\hline & 4 & 8.49 & 7.13 & 0.0001 & 3.28 & 2.81 & 0.0392 \\
\hline \multirow[t]{4}{*}{ Section } & 1 & 7.94 & 4.76 & 0.0001 & 11.44 & 5.82 & 0.0001 \\
\hline & 2 & 7.68 & 5.38 & 0.0001 & 13.11 & 9.20 & 0.0001 \\
\hline & 3 & --- & --- & --- & 12.44 & 9.05 & 0.0001 \\
\hline & 4 & --- & --- & --- & 6.29 & 4.68 & 0.0002 \\
\hline \multicolumn{8}{|c|}{ Length of side shoots ${ }^{z}$} \\
\hline Section & 4 & --- & --- & --- & 59.25 & 58.51 & 0.8178 \\
\hline \multicolumn{2}{|c|}{ Time of budbreak (TB) } & 294.12 & 300.64 & 0.0001 & 277.34 & 286.49 & 0.001 \\
\hline \multicolumn{2}{|c|}{ Tree length } & 165.04 & 169.47 & 0.0598 & 218.12 & 219.46 & 0.5955 \\
\hline \multicolumn{2}{|c|}{ Shoot circumference } & 11.91 & 12.13 & 0.2710 & 16.11 & 15.97 & 0.5351 \\
\hline \multicolumn{2}{|c|}{ Internode length } & 2.28 & 2.26 & 0.2425 & 2.17 & 2.11 & 0.0059 \\
\hline \multicolumn{2}{|c|}{ Total buds } & 72.32 & 75.39 & 0.0024 & 100.15 & 105.22 & 0.0017 \\
\hline \multicolumn{2}{|c|}{ Percent budbreak } & 94.37 & 51.13 & 0.0001 & 51.36 & 28.18 & 0.0001 \\
\hline
\end{tabular}

${ }^{\mathrm{z}}$ ANOVA performed on Log transformed data.

yIndividual seedlings with no budbreak and shoot formation were excluded in the analysis to normalize the distribution for ANOVA. Sections refer to position of tree from lower parts ( $1^{\text {st }}$ section) to top of trees ( $4^{\text {th }}$ section) on which data were recorded. 
A
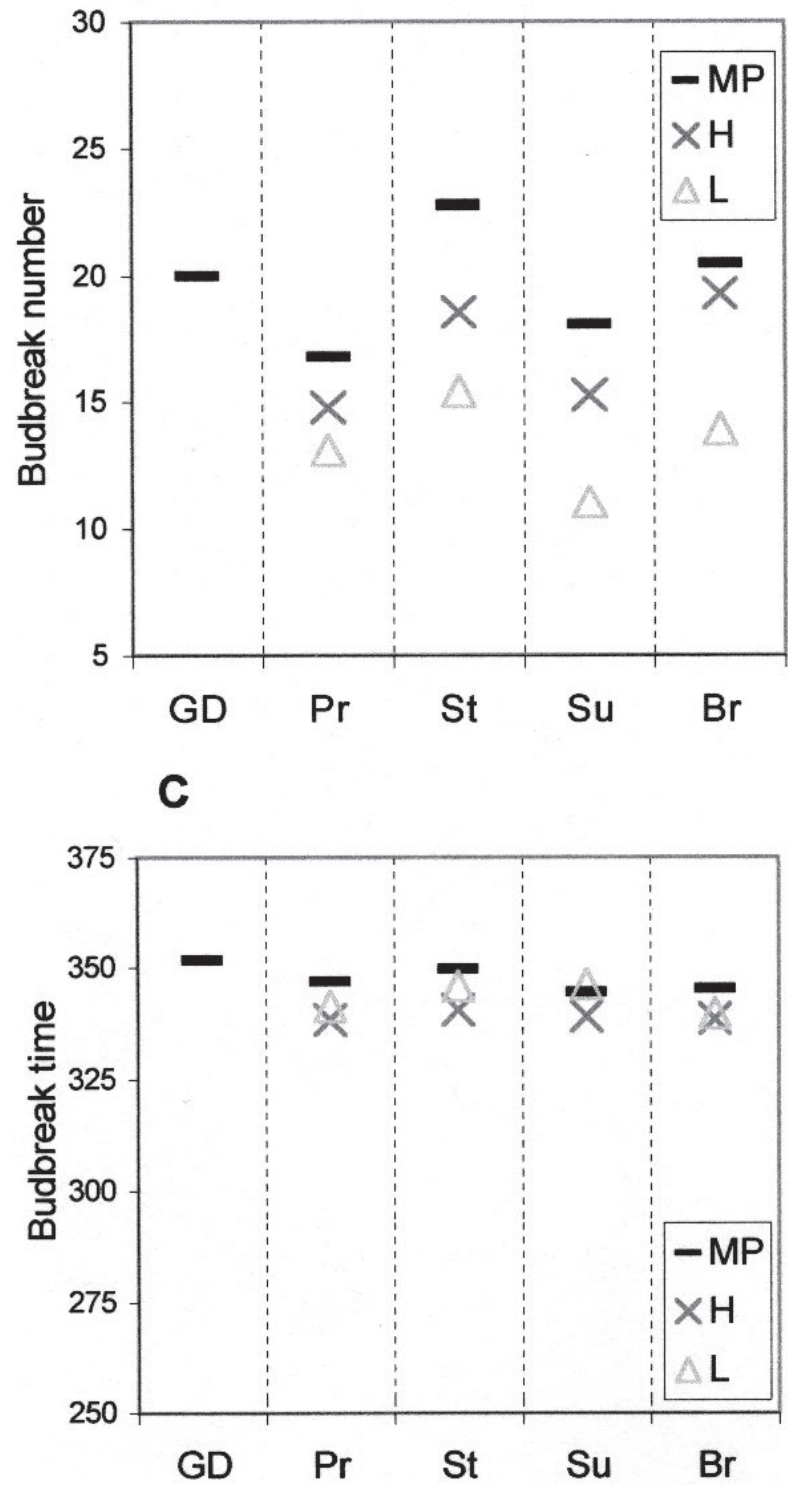

B
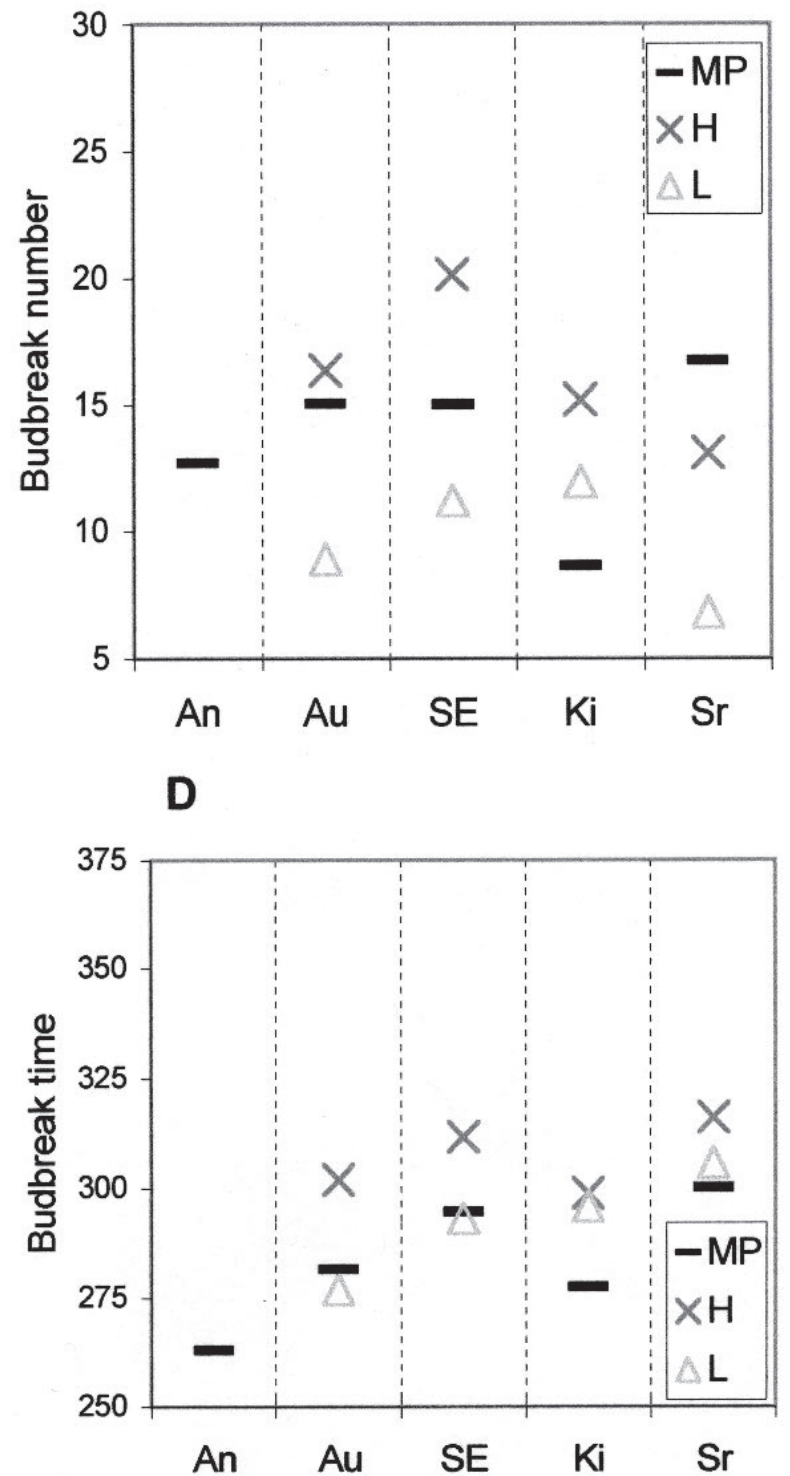

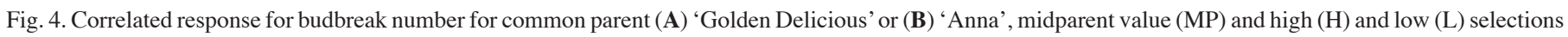
in crosses. Correlated response in budbreak time for $(\mathbf{C})$ 'Golden Delicious' and (D) 'Anna' crosses. 'Golden Delicious' was used as a common parent in crosses with 'Prima' (Pr), 'Starking Delicious' (St), 'Summerking' (Su) and 'Braeburn' (Br). 'Anna' was used as a common parent in crosses with 'Austin' (Au), 'Sharpe's Early' (SE), 'Kirks' (Ki) and 'Summerred' (Sr).

with higher budbreak numbers and side shoot formation compared to the L group. These shoots are known as sylleptic side shoots. Final tree form in orchards depends on the extent of sylleptic shoot formation and lateral branching in the nursery. Sylleptic branching is considered as an advantage for young tree establishment (Cook et al., 2000; Costes and Guédon, 1997). In Expt. II, 'Anna' selections exhibited significantly higher reproductive budbreak and number of side shoots than 'Golden Delicious' selections, in agreement with observations in previous trials under local conditions where 'Anna' families were found to have precocious behavior (ability to flower at a young stage) compared to 'Golden Delicious' families (Labuschagné et al., 2002a).

Variance between families was masked by yearly variation in Expt. I. Parental means for NB in Expt. II suggest that 'Kirks', 'Prima' and 'Anna' have the lowest NB and 'Starking' the highest NB. 'Prima' has repeatedly been found to be low in NB in
Table 4. Mean response to selection for high $(\mathrm{H})$ and low $(\mathrm{L})$ budbreak number averaged over all crosses with mean midparent value (MP) and realized heritability.

\begin{tabular}{lccc}
\hline & \multicolumn{3}{c}{ Mean budbreak no. } \\
\cline { 2 - 4 } & $\begin{array}{c}\text { Selection } \\
(1996-98)\end{array}$ & $\begin{array}{c}\text { Response/MP } \\
(2000)\end{array}$ & $\begin{array}{c}\text { Realized } \\
\text { heritability }\end{array}$ \\
\hline Anna crosses & & $14.35 \pm 1.23$ & \\
MP & & $16.19 \pm 1.80$ & \\
H & 17.33 & $9.69 \pm 1.80$ & \\
L & 7.11 & 12.94 & 0.63 \\
Mean H/L & & & \\
Golden Delicious crosses & & $19.51 \pm 1.23$ & \\
MP & & $16.97 \pm 1.15$ & \\
H & 17.97 & $13.45 \pm 1.15$ & \\
L & 9.09 & 15.21 & 0.40 \\
Mean H/L & & &
\end{tabular}


A

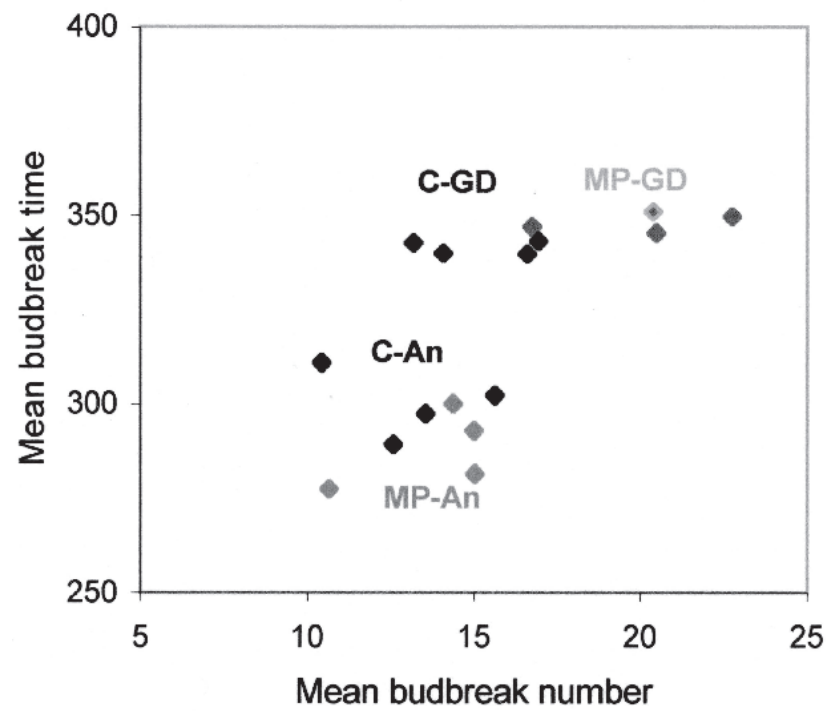

B

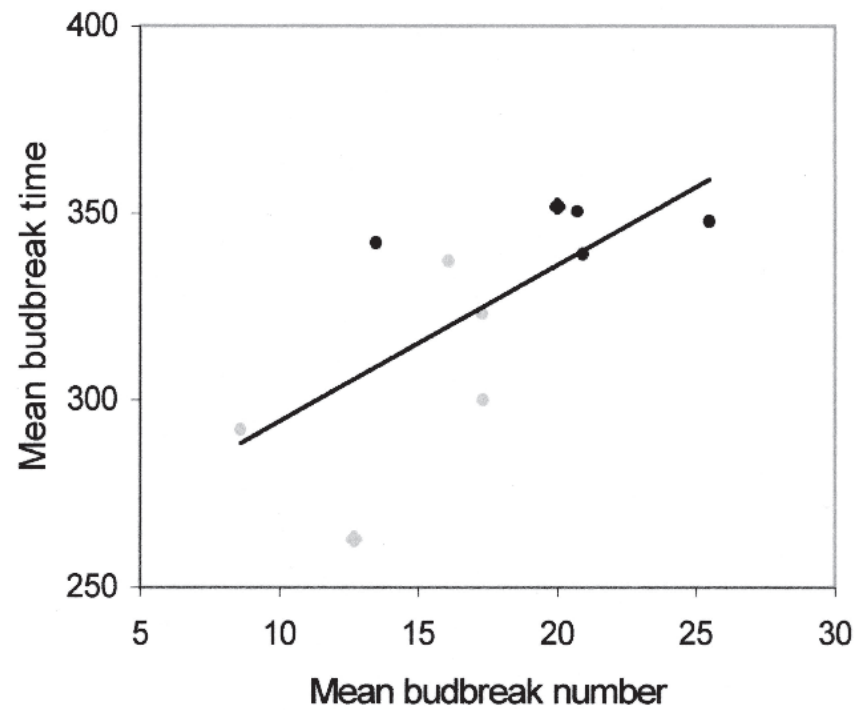

Fig. 5. Genetic associations between budbreak time and budbreak number in groupings according to (A) midparent value and crosses and (B) according to parents alone. MP-GD = midparent values for 'Golden Delicious' crosses; MP-An = midparent values for 'Anna' crosses; C-GD = cross means for 'Golden Delicious' crosses; C-An = cross means for 'Anna' crosses. C-GD and C-An obtained from the means of high and low selection groups.

A

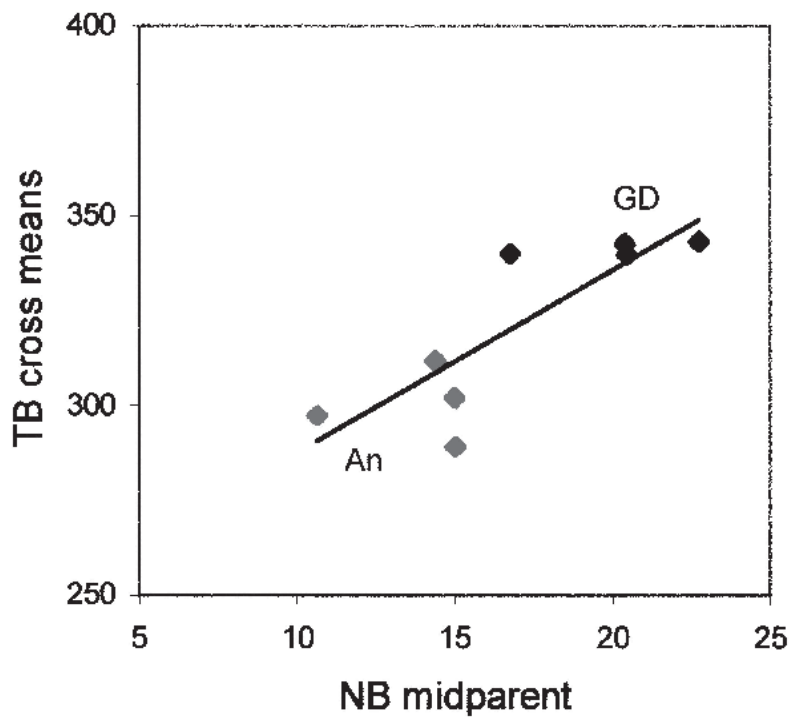

B

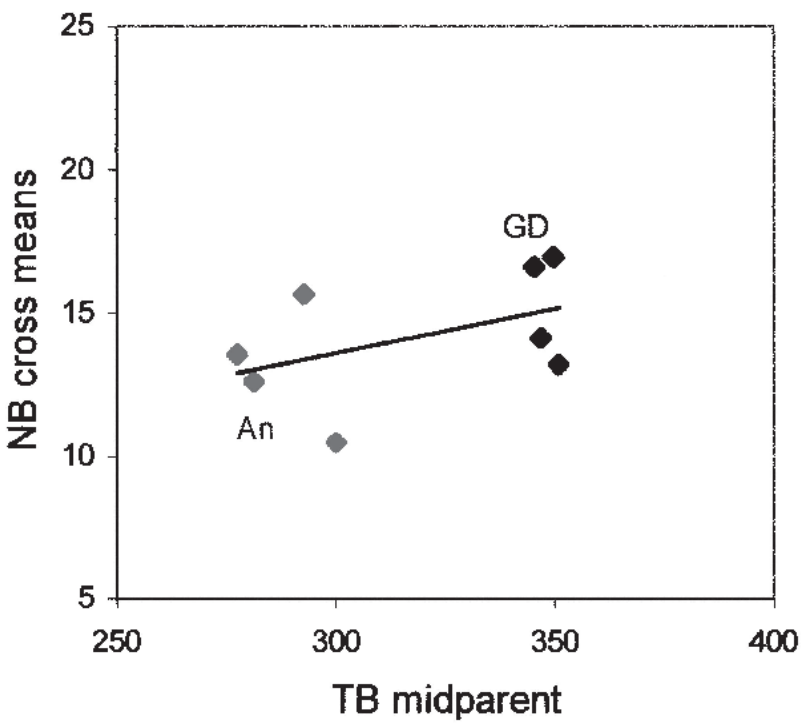

Fig. 6. Regression of cross means for (A) budbreak time (TB) on midparent values of budbreak number (NB) and (B) regression of cross means for budbreak number on midparent values of budbreak time; An = 'Anna' and GD = 'Golden Delicious'.

other experiments (Labuschagné et al., 2002a, 2002b). TB in 'Anna' crosses differed significantly, but not so in the case of 'Golden Delicious' crosses. Differences in TB were also found among the parents. Means between families for the two selection groups showed significant variation for NB. Significant variation in parental means for NB indicates that 'Braeburn' and 'Starking Delicious' can produce higher NB in breeding families. In previous experiments these cultivars have also shown increased budbreak compared to others (Labuschagné et al., 2002a, 2002b).

Association between TB and NB according to midparent values and cross groupings, and according to parental means, imply a positive genetic association between these traits. Based on data collected from adult trees, 'Anna' selections showed earlier TB that occurred over a longer period when compared to 'Golden Delicious' selections. This extended period of budbreak has also been found in the evaluation of adult families (Labuschagné et al., 2002a) and in young clonal families (Labuschagné et al., 2002b). The $\mathrm{H}$ selections of 'Anna' were later in TB than the $\mathrm{L}$ selections and the H selections of 'Golden Delicious' were earlier than the L selections.

Significant response to early selection is considered as a benefit in tree breeding programs because it offers a higher return on the investment (Magnussen, 1988), mainly because the time between first leafing and first bloom may be several years. Many examples of preselection in young seedlings have been described, for example, preselection and secondary traits aiding in selec- 
Table 5. Means for traits in apple seedlings selected for high $(\mathrm{H})$ and low $(\mathrm{L})$ number of budbreak (vegetative plus reproductive buds) based on data collected on adult trees.

\begin{tabular}{|c|c|c|c|c|c|c|c|c|}
\hline \multirow[b]{2}{*}{ Family } & \multicolumn{2}{|c|}{$\begin{array}{c}\text { Time of } \\
\text { budbreak } \\
\text { (TB) }\end{array}$} & \multicolumn{2}{|c|}{$\begin{array}{c}\text { No. of } \\
\text { budbreak } \\
(\mathrm{NB})^{\mathrm{zy}}\end{array}$} & \multicolumn{2}{|c|}{$\begin{array}{c}\text { No. of } \\
\text { reproductive } \\
\text { buds }\end{array}$} & \multicolumn{2}{|c|}{$\begin{array}{l}\text { No. of } \\
\text { side } \\
\text { shoots }^{y x}\end{array}$} \\
\hline & $\mathrm{H}$ & $\mathrm{L}$ & $\mathrm{H}$ & $\mathrm{L}$ & $\mathrm{H}$ & $\mathrm{L}$ & $\mathrm{H}$ & $\mathrm{L}$ \\
\hline Golden Delicious $x$ Starking & 340.48 & 345.90 & 18.55 & 15.39 & 0.16 & 0.14 & 2.31 & 2.20 \\
\hline Golden Delicious x Summerking & 339.21 & 346.24 & 15.27 & 11.05 & 0.33 & 0.25 & 1.16 & 1.75 \\
\hline Golden Delicious x Braeburn & 339.65 & 339.73 & 19.29 & 13.93 & 0.78 & 1.31 & 3.31 & 2.05 \\
\hline Anna $x$ Austin & 301.80 & 276.83 & 16.32 & 8.87 & 2.49 & 7.76 & 7.79 & 5.63 \\
\hline Anna x Sharpe's Early & 311.47 & 292.95 & 20.15 & 11.17 & 2.30 & 2.50 & 5.37 & 3.83 \\
\hline Anna $x$ Kirks & 298.83 & 295.82 & 15.19 & 11.93 & 3.34 & 5.00 & 13.75 & 9.00 \\
\hline Anna $x$ Summerred & 316.13 & 305.66 & 13.08 & 7.80 & 3.09 & 2.40 & 13.70 & 9.30 \\
\hline Mean & $307.02 \mathrm{~b}$ & $292.40 \mathrm{a}$ & $16.32 \mathrm{c}$ & $10.10 \mathrm{a}$ & $6.75 \operatorname{bcd}^{x}$ & $8.61 \mathrm{~cd}^{\mathrm{x}}$ & $12.67 \mathrm{c}^{\mathrm{x}}$ & $9.09 \mathrm{~b}^{\mathrm{x}}$ \\
\hline
\end{tabular}

zWeighted analyses performed.

yANOVA performed on Log transformed data.

xIndividual seedlings with no budbreak and shoot formation were excluded in the analyses to normalize the distrbution for ANOVA.

Across family means separated with general linear models procedure.

Letters indicate significant difference at $P \leq 0.05$.

Table 6. Means for traits of parents that were used in the development of apple families from which seedlings were selected for high and low number of budbreak.

\begin{tabular}{|c|c|c|c|c|}
\hline Parents & $\begin{array}{l}\text { Time of } \\
\text { budbreak } \\
\text { (TB) }\end{array}$ & $\begin{array}{c}\text { No. of } \\
\text { budbreak } \\
(\mathrm{NB})^{\mathrm{zy}}\end{array}$ & $\begin{array}{c}\text { No. of } \\
\text { reproductive } \\
\text { budbreak }\end{array}$ & $\begin{array}{c}\text { No. of } \\
\text { sylleptic } \\
\text { shoots }\end{array}$ \\
\hline Golden Delicious & $351.67 \mathrm{a}$ & $20.01 \mathrm{abcd}$ & $0.33 \mathrm{de}$ & $1.67 \mathrm{c}$ \\
\hline Starking Delicious & $347.73 \mathrm{ab}$ & $25.49 \mathrm{a}$ & $0.00 \mathrm{e}$ & $0.13 \mathrm{de}$ \\
\hline Prima & $341.93 \mathrm{bc}$ & $13.49 \mathrm{de}$ & $2.07 \mathrm{~cd}$ & $0.00 \mathrm{e}$ \\
\hline Braeburn & $338.93 \mathrm{c}$ & $20.93 a b c$ & $5.60 \mathrm{c}$ & $2.80 \mathrm{c}$ \\
\hline Austin & $299.87 \mathrm{e}$ & 17.35 bcde & $13.47 \mathrm{ab}$ & $1.53 \mathrm{c}$ \\
\hline Kirks & $292.00 \mathrm{f}$ & $8.62 \mathrm{f}$ & $1.60 \mathrm{cde}$ & $6.07 \mathrm{~b}$ \\
\hline Anna & $262.93 \mathrm{~g}$ & $12.70 \mathrm{de}$ & $8.50 \mathrm{~b}$ & $10.43 \mathrm{a}$ \\
\hline
\end{tabular}

¿Weighted analyses performed.

yANOVA performed on Log transformed data.

Letters indicate significant differences at $P \leq 0.05$.

Table 7. Analysis of residual variance for NB in High and Low groups in terms of the intraclass correlation coefficient $t$ within crosses and weighting factors $k_{w}$ and $k_{f}$ for combined selection as defined in the text, and for different numbers of clones per cross, $n$. Data for Anna and Golden Delicious refer to Expt. II and Royal Gala to Expt. I.

\begin{tabular}{|c|c|c|c|c|c|c|c|c|c|}
\hline \multirow{2}{*}{$\begin{array}{l}\text { Common } \\
\text { parent }\end{array}$} & & \multirow[b]{2}{*}{ H vs. $L$} & \multicolumn{3}{|c|}{$\begin{array}{l}\text { Clones } \\
\text { within }\end{array}$} & \multirow[b]{2}{*}{$k_{w}$} & \multicolumn{3}{|c|}{$k_{f}$} \\
\hline & & & Crosses & crosses & $t$ & & $n=5$ & $n=10$ & $n=20$ \\
\hline Anna & df & 1 & 3 & 48 & & & & & \\
\hline Golden Delicious & df & 1 & 3 & 48 & & & & & \\
\hline & MS & 228.8 & 104.1 & 28.9 & 0.167 & 0.60 & 1.80 & 2.20 & 2.52 \\
\hline Royal Gala & df & 1 & 9 & 18 & & & & & \\
\hline
\end{tabular}


Table. 8. Correlation over selections for TB and NB based on covariance of data recorded on adult and young seedling clones.

\begin{tabular}{|c|c|c|c|c|c|c|c|}
\hline \multirow[b]{2}{*}{ Family } & \multirow[b]{2}{*}{$\mathrm{N}$} & \multicolumn{3}{|c|}{$\begin{array}{c}\text { Time of } \\
\text { budbreak } \\
\text { (TB) }\end{array}$} & \multicolumn{3}{|c|}{$\begin{array}{c}\text { No. of } \\
\text { budbreak } \\
\text { (NB) }\end{array}$} \\
\hline & & $\begin{array}{c}\text { Mean } \\
\text { adult } \\
\text { seedlings }\end{array}$ & $\begin{array}{c}\text { Mean } \\
\text { young } \\
\text { seedlings }\end{array}$ & $r$ & $\begin{array}{c}\text { Mean } \\
\text { adult } \\
\text { seedlings }\end{array}$ & $\begin{array}{c}\text { Mean } \\
\text { young } \\
\text { seedlings }\end{array}$ & $r$ \\
\hline \multicolumn{8}{|l|}{ H selection } \\
\hline Golden Delicious x Prima & 14 & 278.86 & 338.34 & 0.194 & 15.22 & 14.77 & -0.427 \\
\hline Golden Delicious x Braeburn & 14 & 268.21 & 339.65 & 0.250 & 20.41 & 19.29 & -0.185 \\
\hline Anna $\times$ Austin & 14 & 249.50 & 301.80 & 0.765 & 17.19 & 16.32 & 0.609 \\
\hline Anna x Sharpe's Early & 13 & 257.76 & 311.47 & 0.849 & 17.87 & 20.15 & 0.261 \\
\hline Anna $x$ Kirks & 13 & 249.77 & 298.83 & 0.789 & 17.79 & 15.19 & 0.172 \\
\hline Anna $x$ Summerred & 14 & 255.69 & 316.13 & 0.725 & 16.45 & 13.08 & 0.331 \\
\hline Golden Delicious x Braeburn & 15 & 270.80 & 339.73 & 0.485 & 13.55 & 13.93 & 0.364 \\
\hline Anna $\times$ Austin & 15 & 215.20 & 276.83 & 0.491 & 5.25 & 8.87 & 0.598 \\
\hline Anna x Sharpe's Early & 13 & 223.15 & 292.95 & 0.732 & 5.54 & 11.17 & 0.242 \\
\hline Anna $x$ Kirks & 13 & 229.69 & 295.82 & 0.572 & 7.84 & 11.93 & 0.476 \\
\hline Anna $x$ Summerred & 13 & 247.53 & 305.66 & 0.793 & 8.03 & 7.80 & 0.367 \\
\hline
\end{tabular}

tion for time of bloom in apple (Rodriguez and Sherman, 1985), increase in tree height in Balsam-poplars (Populus balsamifera L.) (Riemenschneider, 1992) and in Black cottonwood (Populus trichocarpa Torr. \& Gray) (Riemenschneider, 1994). In preselection for compact growth habit in apple, the number of side shoots and length to thickness ratio of the central shoot have been found to be good discriminating characteristics (Lapins, 1976). In European plum (Prunus domestica L.) prolonged winter dormancy with a more regular cropping performance was achieved when selecting seedlings with high heat requirements (Wilson, et al., 1975). Criteria used previously to select spur type apples included the density of spurs on 2-year-old shoots, where spur types showed $>20$ spurs per meter, while standards had lower numbers (Blazek, 1992; Warrington, et al., 1990).

In our experiments preselection was based on an easy recognizable character, NB on shoots of 2-year-old intact seedlings planted in plastic bags. The initial assessment was not time-consuming and did not depend on a series of measurements. Response to two-way selection confirms the presence of utilizable genetic variance in seedling families for NB and results indicate that this procedure may be successfully applied as an early screening method for increased budbreak in adult trees. Correlated responses have both adverse and favorable implications for the breeding program. On the one hand, selection for early TB will not be effective in identification of seedlings with increased NB. Selection for NB, on the other hand, may lead to increased shoot formation that may support better tree shapes and easier horticultural manipulation.

From a practical perspective, selection using NB has resulted in superior seedlings with good prospects for improving adaptation to local areas with low chill winter conditions. The positive correlation found between original seedling performance and clonal selection means, further supports the use of NB as one of the most important symptoms of prolonged dormancy. The utilization of genetic variance between crossses (families) should be included in any future breeding program by means of the index combining individual seedling or clone performance within families and the family mean. This will further increase the potential of breeding stock which is of major importance in the improvement of vegetatively propagated cultivars. In this application it should be noted that family size relates to the number of clones per family in such material which in this case also had replicated measurements (trees) within clones. The weight assigned to the family mean $P_{f}$ increases with increase in $n$ and declines with increase in $t$ as predictable, but in material of this nature the magnitude of $t$ can be manipulated by the choice of the clone size, $t$ increasing with increase in clone size. This raises the interesting question of the optimum utilization of limited available resources, i.e., the optimum balance between number of seedlings per cross and clone size when the available space for any one cross is limited. The rate at which selection increases the frequency of seedlings with increased budbreak then depends on the number of seedlings per cross and on the clone size for which the optimum balance under limited facilities available needs to be further explored.

\section{Literature Cited}

Blazek, J. 1992. Segregation and general evaluation of spur type or compact growth habits in apples. Acta Hort. 317:71-79.

Brooks, R.M. and H.P. Olmo. 1972. Register of new fruit and nut varieties. Univ. of California Press, Berkeley.

Champagnat, P. 1978. Formation of the trunk in woody plants, p. 401-422. In: P.B. Tomlinson and M.H. Zimmerman (eds.) Tropical trees as living systems. Cambridge Univ. Press, Cambridge, U.K.

Cook, N.C., E. Rabe, J. Keulemans, and G. Jacobs. 1998. The expression of acrotony in deciduous fruit trees: a study of the apple rootstock M.9. J. Amer. Soc. Hort. Sci. 123:30-34.

Cook, N.C., K. Verhaegen, J. Keulemans, and G. Jacobs. 2000. Manipulation of acrotony in one-year old apple shoots. SA. J. Plant Soil. 17: $108-112$. 
Costes, E. and Y. Guédon. 1997. Modeling the sylleptic branching on oneyear-old trunks of apple cultivars. J. Amer. Soc. Hort. Sci. 122:53-62.

Couraujou, J. 1995. Genetic studies of 11 quantitative characters in apricot. Scientia Hort. 61:61-75.

Dennis, Jr., F.G. 1987. Two methods of studying rest: Temperature alteration and genetic analysis. HortScience 22:820-824.

De Souza, V.A.B and D.H. Byrne. 1998. Heritability, genetic and phenotypic correlations, and predicted selection response of quantitative traits in peach: An analysis of several fruit traits. J. Amer. Soc. Hort. Sci. 123:604-611.

Falconer, D.S. and T.F.C. Mackay. 1996. Introduction to quantitative genetics. 4th ed. Longman, New York.

Hansche, P.E., V. Beres, and R.M. Brooks. 1966. Heritability and genetic correlation in the sweet cherry. Proc. Amer. Soc. Hort. Sci. 88: 173-183.

Hansche, P.E., C.O. Hesse, and V. Beres. 1972. Estimates of genetic and environmental effects on several traits in peach. J. Amer. Soc. Hort. Sci. 97:76-79.

Hauagge, R. and J.N. Cummins. 1991a. Phenotypic variation of length of bud dormancy in apple cultivars and related Malus species. J. Amer. Soc. Hort. Sci. 116:100-106.

Hauagge, R. and J.N. Cummins. 1991b. Genetics of length of dormancy period in Malus vegetative buds. J. Amer. Soc. Hort. Sci. 116: 121-126.

Howe, G.T., J. Davis, Z. Jeknic, T.H.H. Chen, B. Frewen, H.D. Bradshaw, Jr., and P. Saruul. 1999. Physiological and genetic approaches to studying endodormancy-related traits in Populus. Hortscience 34: 1174-1184.

Jacobs, G., P.J. Watermeyer, and D.K. Strydom. 1981. Aspects of winter rest of apple trees. Crop Prod. 10:103-104.

Janick, J., J.N. Cummins, S.K. Brown, and M. Hemmat. 1996. Apples, p. 1-79. In: J. Janick and J.N. Moore (eds.). Fruit breeding. John Wiley and Sons, New York.

Kester, D.E., P. Raddi, and R. Assay. 1977. Correlations of chilling requirements for germination, blooming and leafing within and among seedling populations of almond. J. Amer. Soc. Hort. Sci. 102:145-148.

Labuschagné, I.F., J.H. Louw, K. Schmidt, and A. Sadie. 2002a. Genotypic variation in prolonged dormancy symptoms in apple progenies. HortScience 37:157-163.

Labuschagné, I.F., J.H. Louw, K. Schmidt, and A. Sadie. 2002b. Genetic variation in chilling requirement in apple progeny. J. Amer. Soc. Hort. Sci. 127:663-672.
Lang, G.A., J.D. Early, N.J. Arroyave, R.L. Darnell, G.C. Martin, and G.W. Stutte. 1985. Dormancy: Toward a reduced, universal terminology. HortScience 20:809-812.

Lang, G.A., J.D. Early, G.C. Martin, and R.L. Darnell. 1987. Endo-, para-, and ecodormancy: Physiological terminology and classification for dormancy research. HortScience 22:371-377.

Lapins, K.O., 1976. Inheritance of compact growth type in apple. J. Amer. Soc. Hort. Sci. 101:133-135.

Linsley-Noakes, G.C., P. Allan, and G. Matthee. 1994. Modification of rest completion prediction models for improved accuracy in South African stone fruit orchards. J. S. Afr. Hort. Sci. 4:13-15.

Magnussen, S. 1988. Minimum age-to-age correlations in early selection. For. Sci. 34:928-938.

Mauget, J.C. and R. Rageau. 1988. Bud dormancy and adaptation of apple tree to mild winter climates. Acta Hort. 232:101-108.

Riemenschneider, D.E., B.G. McMahon, and M.E. Ostry. 1992. Use of selection indices to increase tree height and to control damaging agents in 2-year-old balsam poplar. Can. J. For. Res. 22:561-567.

Riemenschneider, D.E., B.G. McMahon, and M.E. Ostry. 1994. Population-dependent selection strategies needed for 2-year-old black cottonwood clones. Can. J. For. Res. 24:1704-1710.

Rodriguez-A.J. and W.B. Sherman. 1985. Relationships between parental, seed, and seedling chilling requirement in peach and nectarine. J. Amer. Soc. Hort. Sci. 110:627-630.

SAS Institute, Inc. 1996. The SAS system. Release 6.12. SAS Inst., Cary, N.C.

Shapiro, S.S. and M.B.Wilk. 1965. An analysis of variance test for normality (complete samples). Biometrika 52:591-611.

Snedecor, G.W. and W.G. Cochran. 1991. Statistical methods. $8^{\text {th }}$ ed. Iowa State University Press, Ames.

Stushnoff, C and H.A. Quamme. 1983. Adaptation to specific climatic and soil environments. p. 269-273. In: J.N. Moore and J. Janick (eds.). Methods in fruit breeding. Purdue Univ. Press, West Lafayette, Ind.

Warrington, I.J., D.C. Ferree, J.R. Schupp, F.G. Dennis, Jr., and T.A. Baugher. 1990. Strain and rootstock effects on spur characteristics and yield of 'Delicious' apple strains. J. Amer. Soc. Hort. Sci. 115: 348-356.

Wilson, D., R.P. Jones, and J. Reeves. 1975. Selection for prolonged winter dormancy as a possible aid to improving yield stability in European plum (Prunus domestica L.). Euphytica 24:815-819.

Wricke, G. and W.E. Weber, 1986. Quantitative genetics and selection in plant breeding. Walter de Gruyter, Berlin. 